\title{
REVENUE AND VALUATION OF COMPANIES WITH DIGITAL PLATFORM BUSINESS MODELS
}

\author{
Przemysław Pomykalski \\ Lodz University of Technology, Lodz, Poland \\ e-mail: przemyslaw.pomykalski@p.lodz.pl \\ ORCID: 0000-0002-9327-8479
}

(C) 2019 Przemysław Pomykalski

This is an open access article distributed under the Creative Commons Attribution-NonCommercial-NoDerivs license (http://creativecommons.org/licenses/by-nc-nd/3.0/)

DOI: $10.15611 / \mathrm{ms} .2019 .1 .02$

JEL Classification: O32, O33, M16, M15, M13

\begin{abstract}
Multisided, digital platforms attract considerable attention in business and academic circles. Seven out of the ten most valuable companies in the world derive much of their value from multisided platforms. The problem of defining and measuring value remains a major challenge in management literature. In this paper I analyze the relationship between the sales (revenue) and market capitalization of companies with digital platform business models. Data was used from a sample of 19 companies that used platform business models in 2017. To assess the correlation, Pearson correlation coefficient was applied. The results indicate that there was a significant positive relationship between revenue and market capitalization in 2017. This suggests that revenue may be used as the main variable in the valuation of companies using platform business models. The results point to future research problems that may be addressed using casebased methodology.
\end{abstract}

Keywords: platforms, business model, valuation.

\section{Introduction}

Multisided platforms attract attention of entrepreneurs and investors. In the third quarter of 2018 the market capitalization of two companies, Apple and Amazon, exceeded one trillion USD and seven of the ten most valuable companies in the world derive much of their worth from multisided platforms. Following their business success, articles appeared not only in business but also in academic literature, especially after Jean Tirole received the Nobel Prize in Economic Sciences for his analysis of market power and regulation. Most studies, at this point, describe platform business models, platform structures and design as conceptual frameworks. As the concept matures and financial data becomes available at least some concepts should be supported using quantitative methods. In this paper I discuss the link between revenue (sales) and value (market capitalization) in companies that use platform business models.

\subsection{Business models}

In 2002 Chesbrough and Rosenbloom observed that "business models were perhaps the most discussed and least understood aspect of the web" [Chesbrough, Rosenbloom 2002]. There are multiple definitions of the business model concept and several comparisons have been published (e.g. [Zott, Amit, Massa 2011; Birkinshaw, Ansari 2015]).

Management literature on business models concentrates on business activities with a network of partners, focusing on cooperation or coopetition [Zott, Amit and Massa, 2011]. Some authors however acknowledge the idea of competition through business models [Casadeus-Masanell, Ricart 2010] and state that business models can be a source of competitive advantage [Markides, Charitou 2004], superior value creation [Morris, Schindehutte, Allen 2005] or reshape entire industries [Magretta 2002].

The popularity of the business model canvas created a milestone in business model considerations in literature. According to Osterwalder and Pigneur 
[2011], the authors of the concept of the business model canvas, the business model "describes the rationale of how an organization creates, delivers and captures value".

As observed by Teece and Linden [2017], consequent definitions based upon Osterwalder and Pigneur dividing the business model into three main categories: value proposition, revenue model and cost model. In this context, value proposition is a marketing term referring to product or service properties (utility) rather than value for shareholders.

The problem of defining and measuring value remains a major challenge in management literature. Teece and Linden [2017] further observe that "a successful business model will provide a customer solution that can support a price high enough to cover all costs and yield profit that is at least sufficient to support the business and its growth". This concept is similar to shareholder value creation based on current and long-term profitability, which in fact is the main driver in the discounted cash flow valuation model [Pomykalska, Pomykalski 2017].

Another context was earlier considered by Amit and Zott [2001] who defined the business model as one that depicts content, structure, and governance of transactions designed so as to create value through the exploitation of business opportunities.

\subsection{Platform}

The word platform has many meanings. The origins of digital platforms in management literature can be traced back to mass production, computer studies and credit cards. Product platforms were described by Wheelwright and Clark [1992]. Works by Bresnahan and Greenstein [1999] and Gawer and Cusumano [2002] focus on the computer industry. Credit card platforms were researched by Rochet and Tirole [2002; 2003] and resulted in a comprehensive theory of multisided markets. After Tirole received the Nobel Prize in Economic Sciences for his analysis of market power and regulation, this concept has attracted considerable attention. This happened at the right moment as applications of digital platforms started to appear in various industries and services.

Reillier and Reillier [2017] define platforms as businesses creating significant value through the acquisition, matching and connection of two or more customer groups to enable them to transact. Van Alstyne, Parker and Choudary [2016] state that platforms provide the infrastructure and rules for a marketplace that brings together producers and consumers.

The European Commission [2016] provided a list of characteristics of platforms:
- they have the ability to create and shape new markets, to challenge traditional ones, and to organize new forms of participation or conducting business based on collecting, processing, and editing large amounts of data;

- they operate in multisided markets but with varying degrees of control over direct interactions between groups of users;

- they benefit from 'network effects', where, broadly speaking, the value of the service increases with the number of users;

- they often rely on information and communications technologies to reach their users, instantly and effortlessly;

- they play a key role in digital value creation, notably by capturing significant value (including through data accumulation), facilitating new business ventures, and creating new strategic dependencies.

\subsection{Platform business models}

Amit and Zott [2001] observed that value creation in e-business goes beyond the configuration of the value chain [Porter 1985], firm-specific core competencies [Barney 1991] or strategic networks [Dyer, Singh 1998] as e-business firms often innovate through novel exchange mechanisms and transaction structures.

The concept of platform business models was introduced recently by Choudary [2013]. In his article it was contrasted with the traditional "pipeline" business model, with input, transformation and output, which was developed by Michael Porter in his value chain [1985].

The platform business model can be seen as a way of creating revenues or as a system of creating value.

Google had to decide how to place advertisements on their site to monetize the popularity of their web browser. Their choice to offer search services free of charge and keep their website without banners allowed them to differentiate from competitive browsers (e.g. Yahoo and AOL) and to succeed in a very competitive market. Their system of selling advertising services is their business model in the context of creating revenue.

To create revenue, platform companies have to attract a critical mass of customers, find a way to match them, connect them, enable them to transact and optimize their system [Reillier, Reillier 2017].

Amazon.com, which started as a book shop, had to attract customers and booksellers, create a system of finding books and information about books (match and connect), enable convenient transaction, payments and delivery and work on optimizing their system. 
Digital platforms are not a homogenous group. They vary in terms of number of users, revenue and its growth rate and in terms of profitability.

\section{Method}

In this paper we use case study methods to create the sample [Yin 2014] and quantitative research analysis (the Pearson correlation coefficient) to assess the correlation between the value (market capitalization) and sales (S2017) of platform companies.

This is a part of a larger study where the multiplecase study procedure described by Yin [2014] was used. Platform companies are identified using descriptive data from their annual reports. The main challenge was to gather accounting and stock market data for quoted and unquoted companies that use platform business models.

As companies in this sample vary in terms of the legal systems in which they are established and operate, accounting systems and currencies, we identify individual companies by figures. Analysis is based on data available to the public.

\section{Data}

The sample consists of 19 companies with the biggest market capitalization which use platform business models, while 17 companies of these are publicly quoted on the stock exchange; data for two companies come from public announcement made by private equity funds.
Market capitalization data was obtained from marcotrends.net (for companies quoted on the NASDAQ, NYSE) and from the Hong Kong Stock Exchange (for Tencent Inc.). Data in Hong Kong Dollars was calculated to USD using the closing exchange rate from 31.12.2017. In addition to the stock quoted companies it was decided to use data for two unquoted companies - Airbnb and Uber - as both often appear in publications referring to platforms.

The market capitalization of Airbnb and Uber was estimated based on private equity financing rounds (data crunchbase.com).

Data on revenue were taken from the annual reports of the quoted companies and news agency reports for Airbnb and Uber.

The companies included in the sample vary with respect to both revenue and market capitalization and an additional description of its specificity is important to understand the results, conclusions and limitations of this study. This approach is consistent with the case study methodology [Yin 1994] adopted for this analysis.

\subsection{Revenue of Platforms}

The prospects of future revenue is a key component in business valuation [Damodaran 2018; Pomykalska, Pomykalski 2018]. The revenue of companies utilizing platform business models, even those founded many years ago, such as: Alphabet (Google) (founded in 1998), Amazon.com (1994) or even Apple (1976) are still growing rapidly (Figure 1). In some companies (Twitter, eBay, TripAdvisor) revenue growth stopped in the last few years.

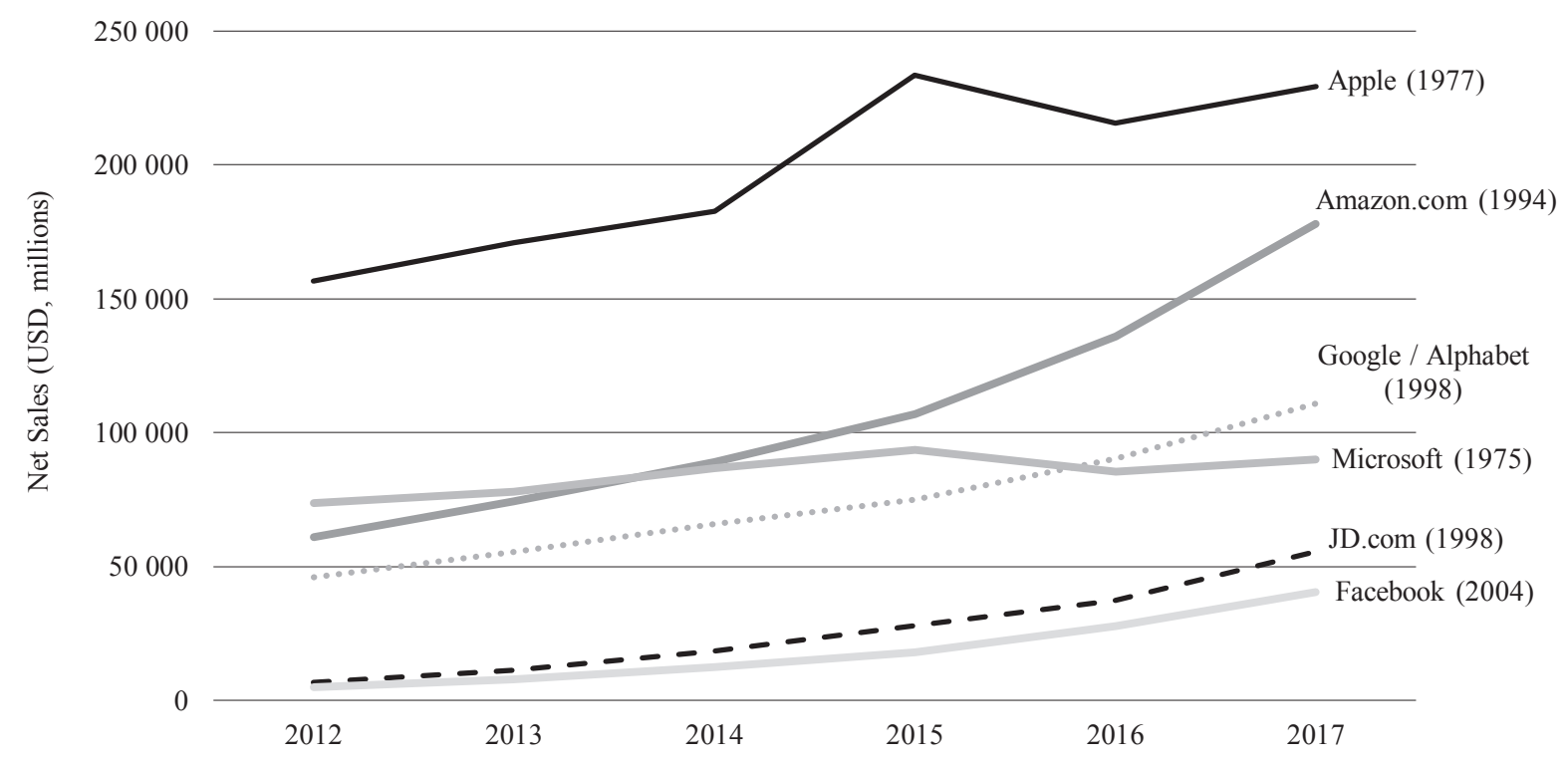

Fig. 1. Revenue of Apple Inc., Amazon.com Inc., Alphabet Inc., Microsoft Inc., JD.com Inc. and Facebook Inc. in 2012-2017 Source: own elaboration based on annual reports. 


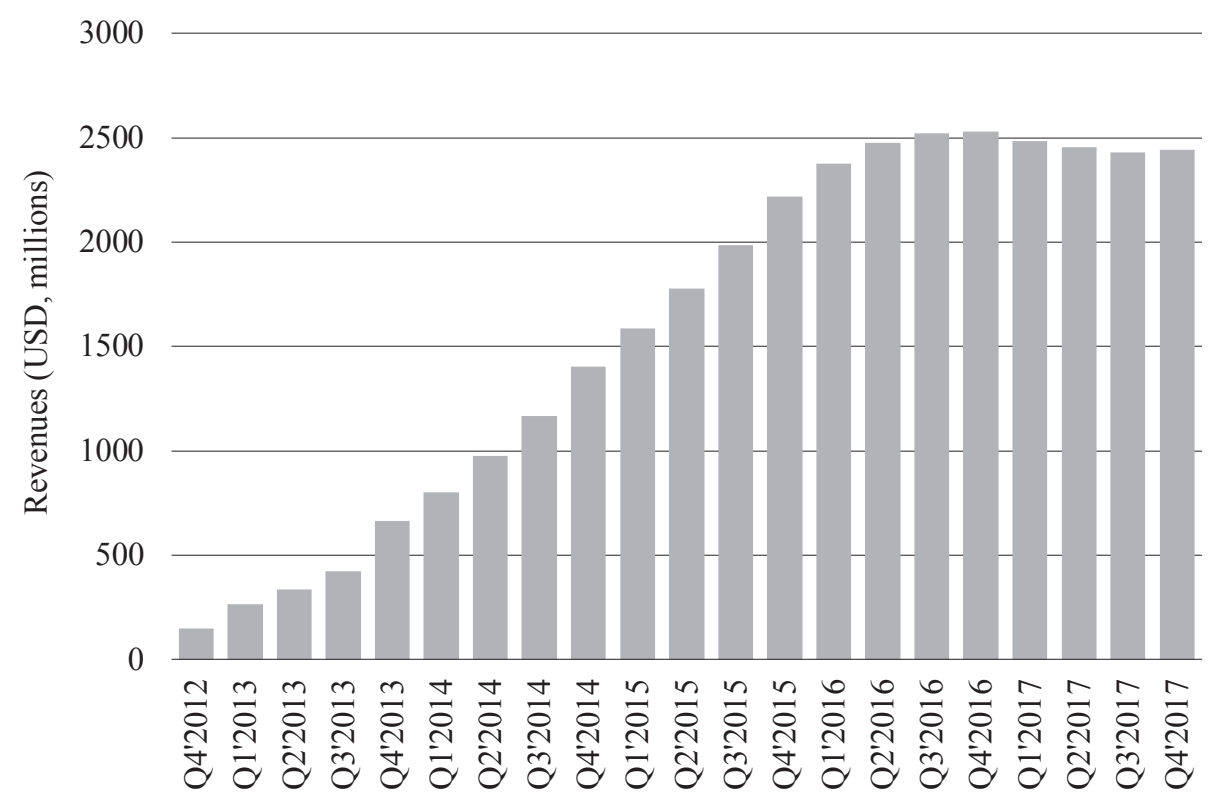

Fig. 2. Revenue of Twitter Q4'2012-Q4'2017

Source: own elaboration, data from the company’s quarterly financial reports.

Although most companies offer their products globally, for some their markets are actually limited to a niche. The growth of revenue in Twitter Inc. followed the traditional product lifecycle curve and seems to have reached maturity in 2016 just 10 years after it was founded (Figure 2). Twitter attracts 335 million users but mainly in English speaking countries.

The customary conclusion that revenue growth slows with time and the value of revenue [Pomykalska, Pomykalski 2017] is not supported in this sample.
Further, it cannot be assumed that smaller companies are "younger" versions of the companies with large revenue that in time will grow to be equal.

\subsection{Value (market capitalization) of platforms}

Market capitalization, the most objective measure of businesses' value, is measured by multiplying the number of shares $(n)$ by the closing price per share $\left(p_{t}\right)$ :

$$
C A P=n \times p_{t} .
$$

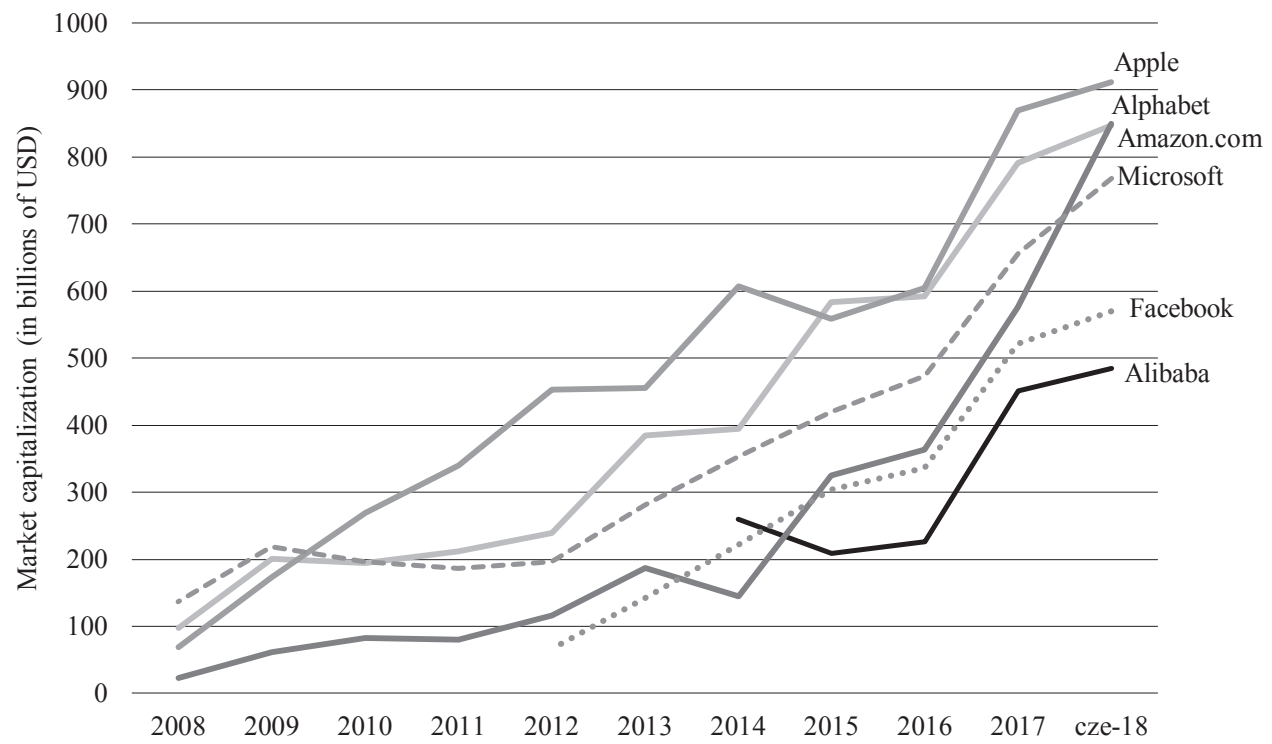

Fig. 3. Revenue of Apple Inc., Amazon.com Inc., Alphabet Inc., Microsoft Inc., Facebook Inc. and Alibaba Inc. in 2012-2017 Source: own elaboration, data from companies' quarterly financial reports. 
The growth in market capitalization can be explained by two main factors: increasing prices on the stock exchange and growing prices of specific stock.

Market capitalization during the last five years of most companies in the sample increased, except for TripAdvisor Inc. In the case of Snapchat Inc. market capitalization fell compared to the IPO (in March 2017). For most of the five companies with biggest market capitalization this growth was constant (Figure 3).

\subsection{The link between revenue and value (market capitalization)}

The growing price of specific stock can be attributed to many factors, depending on the assumptions used by investors. In the DCF valuation model, which is used for fast growing companies, investors often assume the percentage of sales method for forecasting cash flows [Pomykalska, Pomykalski 2017; Damodaran 2018]. In this model, revenue (sales) is the key variable.

Damodaran in his valuations of Amazon, Facebook, Apple and Alphabet clearly points to the differences resulting from business models and value creation decisions, which he divides into investment decisions, financing decisions and dividend decisions [Damodaran 2018]. It should be noted that in his work he is using individual cases, presenting indepth analysis and is not limited to platform business models.
Therefore the business models become "stories" for investors that play a decisive role in their valuations of individual companies.

In this study we examine the link between sales and market capitalization in companies using platform business models. This is part of a larger study investigating the factors that influence the value of platform business models.

\section{Results}

The Pearson correlation coefficient indicates that there is a significant positive relationship between revenue $\left(S_{2017}\right)$ and the market capitalization of companies with digital platform business models $\left(C A P_{2017}\right), r(17)=0.83, p<0.001$. Data for individual companies is depicted in Figure 4 (for all companies) and Figure 5 (focusing on companies with revenue below 50 billion USD and market capitalization under 200 billion USD). The graphic interpretation indicates that for some companies, with revenue approaching 30 billion USD and exceeding 100 billion USD, there may be additional variables (to sales) impacting on valuation. This confirms earlier observations made by Damodaran [2018] on selected companies. The results of this study indicate that revenue (sales) is the key component of the "stories" and valuations of companies using platform business models.

In further research, case-based methods should be used to explain the differences in companies

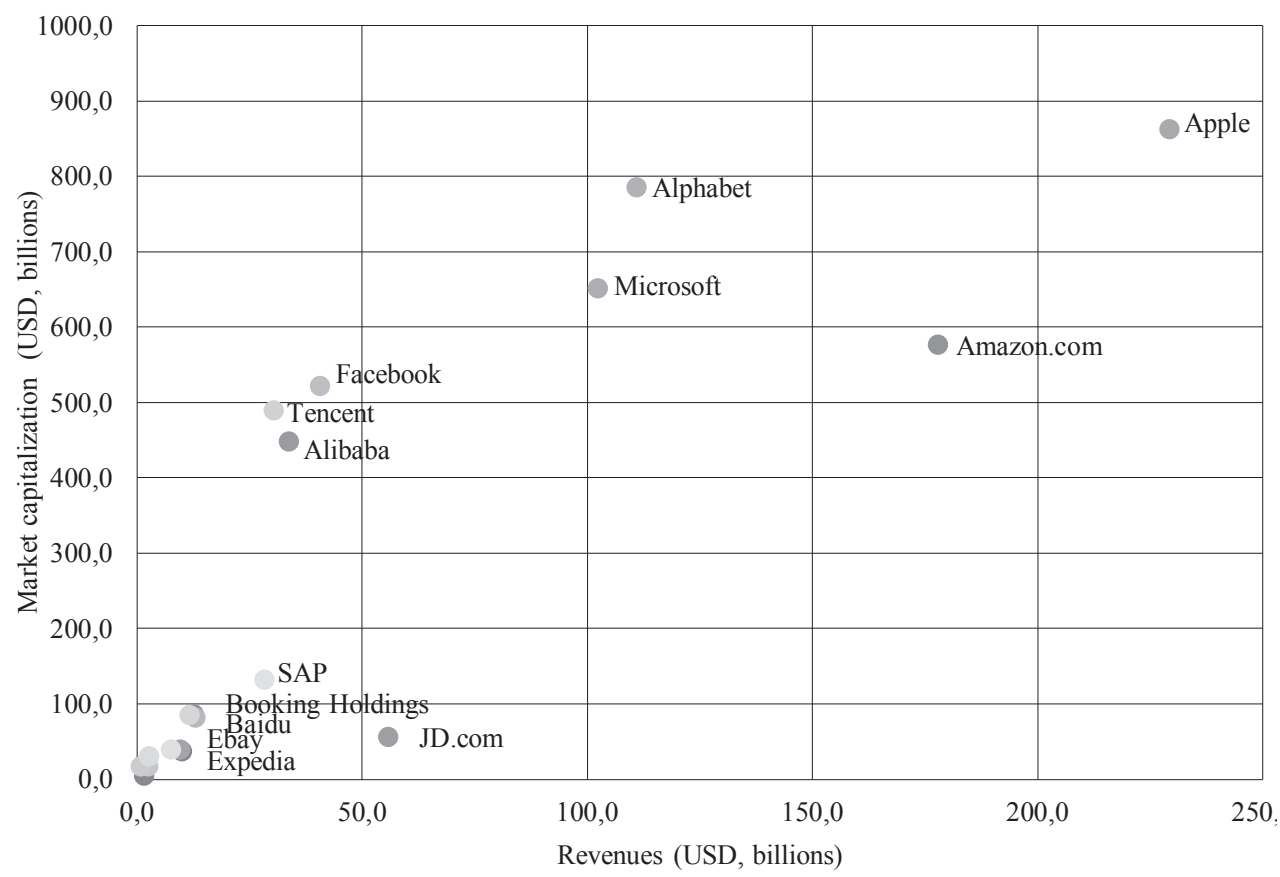

Fig. 4. Market capitalization and revenue of companies using platform business models in 2012-2017

Source: own elaboration, data from companies' quarterly financial reports. 


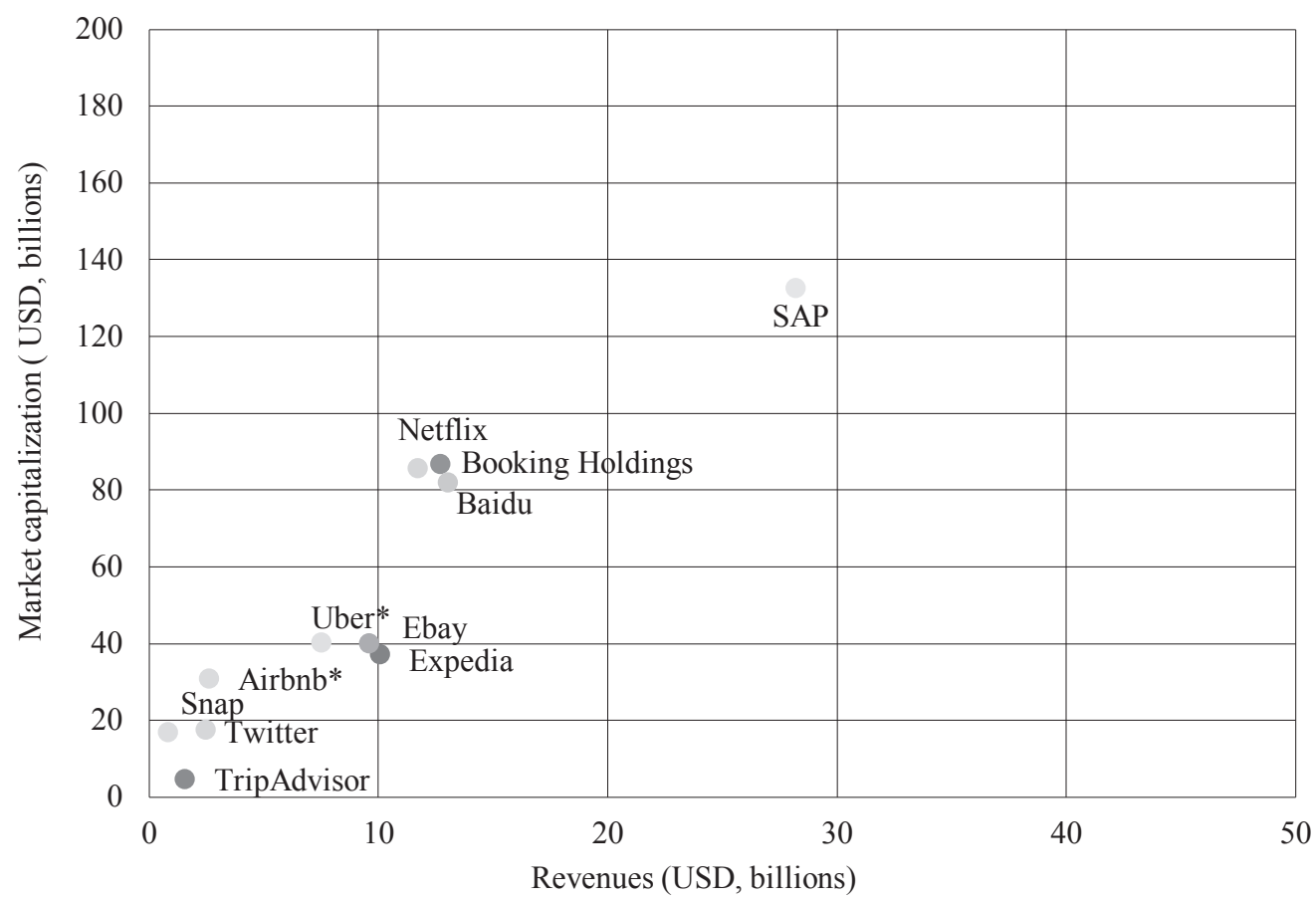

Fig. 5. Market capitalization and revenue of companies using platform business models in the 2012-2017 (revenue $<250$ billion USD and market capitalization $<200$ billion USD)

Source: own elaboration, data from companies' quarterly financial reports.

with revenue exceeding 50 billion USD and market capitalization exceeding 200 billion USD.

\subsection{Limitations}

The combined market capitalization of the companies in this sample, at the end of December 2017 was 4,967,84 billion USD. Total revenue for 2017 amounted to 881 billion USD. Taking into consideration the total revenue and market capitalization, this sample is substantial but it fails to account for start-ups and SMEs, some of which may become major companies in the future.

The time span of this research is limited to one year. This simplifies the calculations and conclusions. Different results may be obtained in a different period. During the last five years the stock market indexes were increasing (bull market) and it is the change from a bull market to a bear market that may provide interesting conclusions, as it did in 2001 and 2008.

A major part of revenue can be attributed to products which are part of platforms but their sales also depend upon other factors. An obvious example is iPhone smartphones in the case of Apple. They contribute to Apple platforms (owners buy apps and media through Apple platforms) and benefit from Apple platforms (functionality provided by apps, access to music and movies) but their sales also depend upon other factors (e.g. technical specifications, price, and the ability to sell in selected markets).

Data for companies quoted in the US, China and Germany are used. Those companies operate under different legal and accounting systems. Stock market valuations are impacted by country risk.

To address the problems related to the diversified characteristics of the companies, individual companies in the graphical interpretation of the analysis were identified.

\section{Conclusions}

The results of the calculation of the Pearson correlation coefficient indicate that there was a significant positive relationship between revenue $\left(S_{2017}\right)$ and market capitalization $\left(C A P_{2017}\right)$ in the sample. This means that revenue may be used as the main variable in the valuation of companies using platform business models. Bigger differences were observed for companies with the highest valuation in the sample. This indicates that other factors may be important and further analysis is required to explain the differences. The results of this study are subject to limitations resulting from the size and characteristics of the companies researched, and the period under research. 


\section{Bibliography}

Amit R., Zott C., 2001, Value creation in e-business, Strategic Management Journal, 22(6-7), pp. 493-520.

Barney J.B., 1991, Firm resources and sustained competitive advantage, Journal of Management, 17, pp. 99-120.

Birkinshaw J., Ansari S., 2015, Understanding Management Models. Going Beyond" What" and" Why" to" How" Work Gets Done in Organizations, [in:] N.J. Foss, T. Saebi, Business Model Innovation: The Organizational Dimension, Oxford Scholarship, pp. 85-103.

Bresnahan T.F., Greenstein S., 1999, Technological competition and the structure of the computer industry, The Journal of Industrial Economics, 47(1), pp. 1-40.

Casadesus-Masanell R., Ricart J.E., 2010, From strategy to business models and to tactics, Long- Range Planning, 43, pp. 195-215.

Chesbrough H., Rosenbloom R.S., 2002, The role of the business model in capturing value from innovation: evidence from $\mathrm{Xe}$ rox Corporation's technology spin-off companies, Industrial \& Corporate Change, 11(3), pp. 529-555

Choudary S.P., 2013, Why business models fail: pipes vs. platforms, Innovation Insights, Wired Magazine, January, 18, 2014.

Damodaran A., 2018, Narrative and Numbers. The Value of Stories in Business, Columbia Business School Publishing, Columbia University Press, New York.

Dyer J., Singh H., 1998, The relational view: cooperative strategy and sources of interorganizational competitive advantage, Academy of Management Review, 23, pp. 660-679.

European Commission, 2016, Communication from the Commission to the European Parliament, the Council, the European Economic and Social Committee and the Committee of the Regions - Online Platforms and the Digital Single Market Opportunities and Challenges for Europe http://eur-lex.europa.eu/legal-content/EN/TXT/PDF/?uri=CELEX:52016DC0288\& from $=\mathrm{EN}$.

Gawer A., Cusumano M.A., 2002, Platform Leadership: How Intel, Microsoft, and Cisco Drive Industry Innovation, Boston, MA, Harvard Business School Press.

Kaleta A., Radomska J., Sołoducho-Pelc L., 2018, The relationship between the approach to strategic management and innovativeness in companies of various sizes, Argumenta Oeconomica, no. 1(40), pp. 203-224.

Magretta J., 2002, Why business models matter, Harvard Business Review, 80, pp. 3-8.

Markides C., Charitou, C.D., 2004, Competing with dual business models: a contingency approach, Academy of Management Executive, 18, pp. 22-36

Morris M., Schindehutte M., Allen J., 2005, The entrepreneur's business model: toward a unified perspective, Journal of Business Research, 58, pp. 726-35.

Osterwalder A., Pigneur Y., 2010, Business Model Generation: a Handbook for Visionaries, Game Changers, and Challengers, John Wiley \& Sons.

Pomykalska B., Pomykalski P., 2017, Analiza finansowa przedsiębiorstwa. Wskaźniki i decyzje w zarzadzaniu, Wydawnictwo Naukowe PWN.

Porter M.E., 1985, Competitive Advantage: Creating and Sustaining Superior Performance, Free Press, New York.

Reillier L.C., Reillier B., 2017, Platform Strategy. How to Unlock the Power of Communities and Networks to Grow Your Business, Routledge.

Rochet J., Tirole J., 2002, Cooperation among competitors: some economics of payment card associations, RAND Journal of Economics (RAND Journal Of Economics), 33(4), pp. 549-570.

Rochet J., Tirole J., 2003, Platform competition in two-sided markets, Journal of The European Economic Association, 1(4), pp. 990-1029.

Teece D.J., Linden G., 2017, Business models, value capture, and the digital enterprise, Journal of Organization Design, 6(1).

Van Alstyne M.W., Parker G.G., Choudary S.P., 2016, Pipelines, platforms, and the new rules of strategy, Harvard Business Review, 94(4), pp. 54-62.

Wheelwright S.C., Clark K.B., 1992, Creating project plans to focus product development, Harvard Business Review, 70(2), pp. 70-82.

Yin R.K., 2014, Case Study Research. Design and Methods, $5^{\text {th }}$ ed., Sage.

Zott C., Amit R., Massa L., 2011, The business model: recent developments and future research, Journal of Management, 37(4), pp. 1019-1042.

\section{PRZYCHODY I WYCENA FIRM STOSUJACYCH MODEL BIZNESU PLATFORMY CYFROWEJ}

Streszczenie: W ostatnich latach platformy cyfrowe przyciągnęły uwagę środowisk biznesu i akademickich. Siedem z dziesięciu spółek o największej kapitalizacji na świecie wykorzystuje model biznesu platformy cyfrowej. Problem definicji i pomiaru wartości pozostaje znacznym wyzwaniem w naukach o zarządzaniu. W artykule przedstawiono wyniki analizy relacji pomiędzy przychodami i kapitalizacją. Wykorzystano dane 19 spółek, które stosowały model biznesu platformy cyfrowej w 2017 roku, i obliczono współczynnik korelacji Pearsona. Wysoki współczynnik korelacji sugeruje, że przychody mogą być wykorzystane w wycenie spółek stosujących model biznesu platformy cyfrowej. Wyniki wskazują również na ograniczenia i problemy, które należy rozwiązywać, wykorzystując metody analizy studiów przypadków ze względu na duże zróżnicowanie badanych spółek.

Słowa kluczowe: platforma, model biznesu, wartość. 


\section{Appendix}

Table 1. Revenues and market capitalization of companies with platform business models.

\begin{tabular}{|l|c|c|}
\hline \multicolumn{1}{|c|}{ USD, billions } & Revenues & Market capitalization \\
\hline Company & S2017 & CAP 2017 \\
\hline Apple & 229,2 & 863,0 \\
\hline Amazon.com & 177,9 & 576,6 \\
\hline Alphabet & 110,9 & 785,6 \\
\hline Microsoft & 102,3 & 651,1 \\
\hline JD.com & 55,7 & 56,4 \\
\hline Facebook & 40,7 & 521,6 \\
\hline Alibaba & 33,8 & 448,2 \\
\hline Tencent & 30,4 & 490,0 \\
\hline SAP & 28,2 & 132,6 \\
\hline Baidu & 13,0 & 81,9 \\
\hline Booking Holdings & 12,7 & 86,8 \\
\hline Netflix & 11,7 & 85,8 \\
\hline Expedia & 10,1 & 37,4 \\
\hline Ebay & 9,6 & 40,2 \\
\hline Uber* & 7,5 & 40,3 \\
\hline Airbnb* & 2,6 & 31,0 \\
\hline Twitter & 2,4 & 17,6 \\
\hline TripAdvisor & 1,6 & 4,8 \\
\hline Snap & 0,8 & 17,0 \\
\hline
\end{tabular}

* Market capitalization is estimated based on most recent funding round.

Source: own.

Table 2. Regression statistics of revenues $\left(S_{2017}\right)$ and market capitalization $\left(C A P_{2017}\right)$

\begin{tabular}{|l|r|}
\hline \multicolumn{2}{|c|}{ Regression Statistics } \\
\hline Multiple R & 0,831247854 \\
\hline R Square & 0,690972995 \\
\hline Adjusted R Square & 0,672794936 \\
\hline Standard Error & 169,5232112 \\
\hline Observations & 19 \\
\hline
\end{tabular}

ANOVA

\begin{tabular}{|l|c|c|c|c|c|}
\hline & $d f$ & $S S$ & $M S$ & $F$ & Significance F \\
\hline Regression & 1 & 1092375,382 & 1092375,382 & 38,01137356 & $1,03714 \mathrm{E}-05$ \\
\hline Residual & 17 & 488548,0254 & 28738,11914 & & \\
\hline Total & 18 & 1580923,407 & & & \\
\hline
\end{tabular}

\begin{tabular}{|l|c|c|c|c|c|c|c|c|}
\hline & Coefficients & Standard Error & $t$ Stat & P-value & Lower 95\% & Upper 95\% & Lower 95,0\% & Upper 95,0\% \\
\hline Intercept & 86,17373983 & 48,17569969 & 1,788738729 & 0,091490834 & $-15,46810185$ & 187,8155815 & $-15,46810185$ & 187,8155815 \\
\hline S2017 & 3,738389807 & 0,606356172 & 6,165336451 & $1,03714 \mathrm{E}-05$ & 2,459090111 & 5,017689504 & 2,459090111 & 5,017689504 \\
\hline
\end{tabular}

Source: own. 